\title{
Okulların Örgütsel Öğrenmeleri İle Öğretmenlerin Örgütsel Sessizlik Düzeyleri Arasındaki İlişki ${ }^{1}$
}

\author{
Fatma DEMIRBAŞ $^{2}$ ve Aynur B. BOSTANCI ${ }^{3}$
}

Öz

Bu araştırmada, okulların örgütsel öğrenmeleri ile öğretmenlerin örgütsel sessizlik davranışları arasındaki ilişkinin belirlenmesi amaçlanmıştır. Araştırma ilişkisel tarama modelindedir. Araştırmanın evrenini 2019-2020 öğretim yılında Kütahya ilinin Gediz ilçesinde görev yapan 610 öğretmen, örneklemini ise 404 ilkokul, ortaokul ve lise öğretmeni oluşturmaktadır. Araştırmada kolay ulaşılabilir örnekleme yoluna gidilmiştir. Araştırma verileri "Örgütsel Öğrenme Ölçeği” ve "Öğretmenler için Örgütsel Sessizlik Ölçeği” ile toplanmıştır. Araştırma verileri aritmetik ortalama, tek yönlü varyans analizi, Pearson Momentler Çarpımı Katsayısı ve Çoklu Regresyon Analizi ile analiz edilmiştir. Araştırmaya göre, öğretmenlerin okullarda örgütsel öğrenmeye yönelik alg1 düzeylerinin yüksek olduğu görülmektedir. Yine okullarda örgütsel öğrenmeye yönelik öğretmen algılarının, çalışılan okul düzeyine göre anlamlı farklılık göstermektedir. Öğretmenlerin okullarda örgütsel sessizliğe yönelik algıları ise düşük düzeydedir. Öğretmenlerin örgütsel sessizlik düzeyi algıları, çalışılan okul düzeyi göre anlamlı olarak farklılaşmaktadır. Araştırmanın başka bir sonucuna göre de, öğretmenlerin okullardaki örgütsel öğrenme algıları ile örgütsel sessizlik düzeyleri arasında negatif yönlü orta dereceli bir ilişki tespit edilmiştir. Son olarak araştırmada, öğretmenlerin okullarda örgütsel öğrenmeye yönelik algılarının, örgütsel sessizlik düzeylerini anlamlı bir şekilde yordadığ1 görülmüştür.

Anabtar Kelimeler: Okullarda örgütsel öğrenme, Öğrenen örgüt, Sürekli öğrenme, Örgütsel sessizlik

\section{The Relationship between Organizational Learning of Schools and Organizational Silence Levels of Teachers}

\section{Abstract}

This study aims to determine the relationship between organizational learning of schools and teachers' organizational silence behaviors. The research is in relational survey model. The universe of the research consists of 610 teachers working in Gediz district of Kütahya province in the 2019-2020 academic year; and the sample consists of 404 primary, secondary and high school teachers. Convenience sampling method has been adopted in the research. The research data have been collected with "Organizational Learning Scale" and "Organizational Silence Scale for Teachers". The data have been analyzed with arithmetic mean, one-way analysis of variance, Pearson ProductMoment Coefficient and Multiple Regression Analysis. According to the research, it is seen that teachers' perception levels of organizational learning in schools are high. Again, it has been seen that the perceptions of teachers towards organizational learning in schools differ significantly according to the level of school they work at. Teachers' perceptions of organizational silence in schools are at a low level. Teachers' perceptions of organizational silence level in schools differ significantly according to the level of school they work at. According to another result of the research, a moderate negative relationship has been found between teachers' perceptions of organizational learning and their levels of organizational silence in schools. Finally, it has been observed in the research that teachers' perceptions of organizational learning in schools have significantly predicted their organizational silence levels.

Key Words: Organizational learning in schools, Learning organization, Continuous learning, Organizational silence

\section{Atıf İçin / Please Cite As:}

Demirbaş, F. ve B., Bostancı, A. (2020). Okulların örgütsel öğrenmeleri ile öğretmenlerin örgütsel sessizlik düzeyleri arasındaki ilişki. Manas Sosyal Araştırmalar Dergisi, 9(3), 1426-1439.

Geliş Tarihi / Received Date: 02.06.2020

Kabul Tarihi / Accepted Date: 25.06.2020

\footnotetext{
${ }^{1}$ Bu makale Uşak Üniversitesi Lisansüstü Eğitim Enstitüsü’nde ikinci yazarın danışmanlığında yürütülen aynı konulu yüksek lisans tezinden üretilmiştir.

2 Öğretmen - Kütahya Gediz Milli Eğitim Müdürlüğü, fatmademirbas672@gmail.com -ORCID: 0000-0003-2302-9810

${ }^{3}$ Doç. Dr. - Uşak Üniversitesi Eğitim Fakültesi, aynur.bozkurt@usak.edu.tr - ORCID: 0000-0002-7927-6063
} 


\section{Giriş}

Örgütler belirli amaçları gerçekleştirmek için kurulmuştur. Örgütlerin amaçlarına ulaşabilmesinde, üstlenmiş oldukları işlevleri beklentiler doğrultusunda yerine getirebilmeleri önemlidir. Her geçen gün bu beklentilerde değișimler yașanmaktadır. Örgütlerin bu değișimlere cevap verebilmesi için sürekli öğrenmeleri gerekmektedir. Örgütsel öğrenme kavram1 1950'lili yıllarda ortaya atılmıştır. 1980'lerden itibaren yaşanan değişim ve bilgi patlaması doğrultusunda, alanda ilginin daha da arttı̆̆ bir kavram olmuştur. İlk dönemlerde örgütsel öğrenme, örgüt problemlerinin çözümü ve örgüt işlevlerinin iyileştirilmesi için önemsenmiştir. Örneğin örgütsel öğrenmeye yönelik ilk çalışmayı yapan Argyris ve Schön (1978) örgütsel öğrenmeyi, hataların belirlenip ortaya çıkarllmasıyla öğrenme süreci olarak görmüşlerdir. Daha sonraki ylllarda örgütsel öğrenmeye, örgütün daha iyi olabilmesi için düşünmeye başlaması olarak bakılmaya başlanmıştır. Özellikle 1990’lı yıllarda Peter Senge'nin "Beşinci Disiplin" adlı kitabıyla örgütsel öğrenme kavramına ilgiyi oldukça artmış ve bu ilgi halen varllğını sürdürmektedir. Senge (1990) örgütün istediği sonuçlara ulaşabilmesinde çevresini göz önünde bulundurarak kendi kapasitesini sürekli geliştirmesi için öğrenmesi gerektiğini vurgulamıştır (Kapu ve Aybas, 2008, s. 82; Keklik, Kılıç, Yildız ve Yildız, 2015, s. 131; King1r ve Mesci, 2007, s. 64; Mert, 2018, s. 53).

Örgütsel öğrenme, örgütlerin çevredeki hızla değişen koşullara uyum sağlamaları ve başarılarını arttırmaları için firsatlar sunmaktadır. Örgütsel öğrenme örgütsel süreklilik, gelişime ve büyüme için gerekli bilgi, yetenek, değer ve davranış biçimlerinin elde edilmesi ve gösterilmesi olarak tanımlanabilmektedir (Basım ve Şeşen, 2008 s. 7). Başka bir tanıma göre de örgütsel öğrenme, örgütlerin gelişimine yönelik bilgilerinin ve yeterliliklerinin belirlenerek, örgüt çalışanlarının etkinliklerinin artırılması ve çeşitlendirilmesi için çalışan yeteneklerinin iyileştirilmesi sürecidir (Turan, Karadağ ve Bektaş, 2011, s. 629). Örgütlerde öğrenmenin temeli öğrenen çalışandır. Öğrenen takımları ve sonuçta öğrenen örgütü yaratacak olan öğrenen çalışandır (Bozkurt, 2003, s. 43)

Örgütsel öğrenme, örgütlerde bireysel, takım halinde ve örgütsel düzeyde olmak üzere üç şekilde gerçekleşmektedir. Bireysel öğrenme, örgüt çalışanlarının bireysel olarak yeni bilgiler elde ederek işi için yorumlaması ve davranışlarını buna göre şekillendirmesidir. Takım halinde öğrenme ise, örgüt içinde bireysel ve diğer öğrenmelerin paylaşılması, öğrenilenlerin beraber yorumlanması ve bunların grup davranışına yansıtılmasıdır. Örgütsel öğrenmede, takım halinde oluşturulan öğrenmenin örgütün hafızasına kaydedilmesidir (Aydınlı, 2005 s. 93; Bozkurt, 2003, s. 52; Fidanboy, Serpoush ve Yeloğlu, 2014, s. 753; Pinar, 2006, s. 30; Yılmaz ve Görmüş, 2012, s. 4491). Çünkü örgütsel öğrenme, kolektif bir süreçtir. Örgütteki ortak tecrübelere, normlara ve ortak alınan kararlara dayanmaktadır (Düren, 2000, s. 137).

Örgütlerde öğrenme tek yönlü, çift yönlü ve öğrenmeyi öğrenme olmak üzere üç şekilde gerçekleşmektedir. Tek yönlü öğrenme örgütün, belirlediği hedefe ulaşamamasını engelleyen hataları düzeltirken öğrenmesidir. Örgüt, duruma göre davranışlarında değişim oluşturarak çevreye uyum sağlayarak hatalarını düzeltmeye çalışmaktadır. Çift yönlü öğrenmede, sadece davranış değiştirmekle kalınmamakta; örgütün kültürü, amaçları, stratejisi ve yapısını da değiştirilerek sorunlara kökten çözüm getirilmesiyle oluşmaktadır (Ayden ve Düşükcan, 2002, s. 124; Aydınlı, 2005, s. 86; Çalık, 2003, s. 118; Peker, 1995, s. 216; Yazıc1, 2001, s. 106). Öğrenmeyi öğrenmede ise, örgütsel öğrenme stratejilerinin, yapılarının ve öğrenmeye katkı yapacak süreçlerinin değerlendirilmesi sağlanmaktadır. Örgütte sürekli örgüt yararına bilgi elde edilmesi, elde edilen bilgilerin paylaşılması, benimsenmesi, kullanılması ve yeni bilgi üretilmesi gerçekleşmektedir (Aydınlı, 2005, s. 88; Balay, 2004, s. 37; Çemberci, 2013, s. 101; Karahan ve Yllmaz, 2010, s. 141; Yazıc1, 2001, s. 113).

Örgütsel öğrenmenin gerçekleşebilmesi için öncelikle örgüt içindeki öğrenme engellerini yok etmek gerekmektedir. Örgütlerde öğrenmeyi engelleyen unsurlar Senge'ye göre (2007, s. 27) şu şekilde açıklanabilmektedir. (1) Örgüt çalışanların sadece çalıştıkları pozisyonu benimseyip, diğer pozisyonlardaki sorunlara kayıtsız kalmaları ve sorumluluk almamaları, (2) işler yolunda gitmediğinde sorumluların dışarıda aranması ve bahaneler üretilmesi, (3) ortaya çıkan sorunların giderilmesinde, bir başkasının sorumluluk almasının beklenmesi, (4) kısa zaman dilimlerinde yaşanılan olaylara takılıp kalınması, (5) hataların geç fark edilmesi nedeniyle eyleme geçecek zamanın kalmaması, (6) tüm sorunların edinilen tecrübelerle çözülebileceğinin düşünülmesi ve (7) örgüt yöneticilerinin kriz durumlarında yetersiz olmalarıdır. Basım ve Şeşen de (2008, s. 18) örgütsel öğrenme engellerini, olaylardan ders çıkarmama, sorunlar arası ilişki kuramama, bilgi paylaşmama, sorunu görüp de görmezden gelme ve sorunları kabul etmeme olarak belirlemektedirler. Gordon (2009) da okullar için öğrenme engellerini okullardaki hiyerarşik yapı nedeniyle 
öğretmenlerin emir altında olması, okullarda öğretmenlerin karar aşamalarında söz sahibi olamamaları, okul çalışanlarındaki değişime yönelik katılık ve direnç, okullarda yaratıcı olmayan tekdüze kalıp kararların uygulanması olarak dile getirmektedir (Çantuş, 2012, s. 36). Okullarda örgütsel öğrenme için ortam oluşturmayan ve öğrenme engellerinin bulunduğu okullarda da öğretmenlerin örgütsel sessizlik düzeylerinin yüksek olacağı düşünülebilmektedir. Örgütsel sessizlik düzeyinin yüksek olduğu okullarda da öğretmenler, okul yönetimi ile iletişim kurmayarak okulun gelişimine yönelik fikir ve önerilerini açıklamamaktadırlar. Bunun sonucunda, okulda bilgi paylaşımları yetersiz kalmakta, öğretmenlerin ve yöneticilerin performansları düşmekte ve örgütsel ortamda sinerji oluşmamaktadır (Cemaloğlu, 2012, s. 202).

Örgütsel sessizlik, örgütün iyileşmesi ve vizyonunu gerçekleştirebilmesi için örgüt çalısanlarının bilinçli bir şekilde duygularını, düşüncelerini, fikir ve görüşlerini esirgemesidir (Kahveci ve Demirtaş, 2013, s. 52). Örgütsel sessizlik, örgüt çalışanlarının kasıtlı olarak, örgüt içinde gerçekleşen her türlü durma yönelik görüş ve düşüncelerini tepkilerden çekinme, korkma veya fikrinin herhangi bir farklilık getirmeyeceği düşüncesiyle açıklamaktan kaçınması olarak da açıklanabilmektedir (Taşkıran, 2011, s. 72). Örgütsel sessizlikte çalışan sahip olduğu bilgileri bilinçli ve istekli olarak sessizliğini koruyarak örgütten saklamaktadır (Eroğlu, Adıgüzel ve Öztürk, 2011, s. 100).

Alanyazın incelendiğinde örgütsel sessizlik ile ilgili yapılan ilk tanım 1970 yllında Hirschman'a aittir. Örgütsel sessizliğe yönelik ilk çalışma ise, Morrison ve Milliken (2000)tarafından yapılmıştır. Bu çalışmada örgütsel sessizliğin örgütte içinde ortaya çıkmasını, gelişimini ve örgütsel sessizliğin devamlılı̆̆ını sağlayan etkenler incelemiştir Örgütsel sessiz günümüzde oldukça ilgi duyulan bir kavramdır (Aydın, 2016, s. 167; Eroğlu vd, 2011, s. 99; Yaman ve Ruçlar, 2014, s. 37). Örgütlerde sessizlik kavramı, başlangiçta örgüte bir bağlllık olarak algılansa da aslında çalışanların örgütsel konu ve sorunları ile ilgili bilgisinin olmasına rağmen, bilgisini bilinçli olarak saklaması şeklinde betimlenen istenmeyen bir durumdur (Çakıc1, 2010, s.10). Çünkü günümüz şartlarında örgüt çalışanlarının daha çok inisiyatif almalarına, yeni görevler üstlenmelerine, görüşlerini açılamalarına, eleştirilerini açıkça dile getirmelerine ve bilgileri örgüt yararına paylaşmalarına gereksinim duyulmaktadır. Bunun için örgütlerde ortaya çıkan sessizlik doğru analiz edilmeli ve gerekçesi her ne olursa olsun örgütün işleyişine zarar vermesi engellenmelidir (Çakıcı, 2010, s. 32; Üçok ve Torun, 2015, s. 30).

Örgütsel Sessizlik örgütlerde üç şekilde görülebilmektedir. Bunlar kabullenici, korunmacı ve korumacı sessizliktir. Kabullenici sessizlik, örgüt çalışanlarının herhangi bir konu, sorun ya da durum ile ilgili tüm gelişmeleri kabullenerek, söz konusu durum hakkındaki görüsslerini söylememesidir (Taşkıran, 2011, s. 72; Tayfun ve Çatır, 2013, s. 116). Korunmacı sessizlik, korku ve tamamen kendini korumak düşüncesiyle örgüt çalışanının konuyla ilgili fikir, bilgi ve görüşlerini açıklamaktan sakınmasıdır (Şehitoğlu ve Zehir, 2010, s. 89; Kahveci ve Demirtaş, 2013, s. 53)Korumac1 sessizlik ise, örgüt içi birlik ve düzenin bozulmaması için, örgütü koruma amaçlı olarak örgüt çalışanlarının örgüt yararına bilgi ve görüşlerini gizlemesi olarak açıklanabilmektedir (Gül ve Özcan, 2011, s. 112; Çakıc1, 2010, s. 34).

Okullarda gelişim ve değişimin gerçekleşmesini engelleyen örgütsel sessizlik nedenlerine yönelik çalışmalar yapilması ve sessizlik için çözüm yollarının bulunması gerekmektedir (Bayram, 2010, s.4). Arlı (2013, s. 79), araştırmasında örgütsel sessizliğin okul için sonuçlarını öğretmenlerin mutsuzluğu, agresif davranış göstermeleri, işe bağll1ık-sahiplenmenin azalması, gelişim ve değişim karşıtlığı, pasif olma, performans ve düşmesi ve örgütsel vatandaşlık göstermeme ve adalet algisındaki azalma olarak belirlenmiştir. $\mathrm{Bu}$ araştırmadan da anlaşılacağ üzere, örgütsel sessizlik öğretmenler ve okul için olumsuz sonuçlara sebep olmaktadır. Ayrıca örgütsel sessizlik, çalışanların problemlerin gizlenmesi, fikirlerin paylaşılmaması, olumsuz eleştiriden kaçınma sorunlar karşısında kayıtsız kalma gibi durumların oluşmasına yol açmaktadır. Çalışanların açısından ise, örgüte güven, bağlılık, aidiyet, takdir ve destek duygusunda azalma, kendilerini değersiz hissetme, iş tatmini elde edememe, işten ayrılma isteği şeklinde görülmektedir. Böylelikle örgütsel sessizlik örgütlerde doğru karar vermeyi, gelişmeyi ve performans artışını istenmeyen yönde etkilemektedir (Çakıc1, 2008, s. 119; Milliken ve Morrison, 2003, Akt: Yalçınsoy, 2019, s. 73; Uçar, 2017, s. 11). Ayrıca örgütlerde ortaya çıan sorun ve konulara ilişkin açıkça konuşmama kararı yani 'sessizlik' örgütsel değişim ve gelişime engel oluşturduğu için örgütte farklı fikirlerin ortaya çıkmasını azaltarak yenilikçiliği ve yaratıcllı̆ı olumsuz yönde etkilemektedir (Ünlü, Hamedoğlu ve Yaman, 2015, s. 142). Çünkü Sürekli farklılaşan şartlar, okulların etkililiğini, kalitesini ve verimliliğini sürdürebilmeleri için örgütsel öğrenmenin yüksek olan kurumlar olmasını gerektirmektedir. Örgütsel öğrenme, bir grup oluşturan insanların ortak amaçlar için birlikte hareket edip belirlenen amaçlara ulaşmak adına sürekli 
olarak daha etkili ve etkin yollar geliştirmelerini zorunlu kılmaktadır (Kurt, 2016 s.10; Töremen 2001 s.45). Örgütsel sessizliğin olduğu bu okulda bu durumu mümkün görülmemektedir.

Örgütsel öğrenme için örgütler, öğrenmeyi teşvik eden, çalışanlarını geliştirmeyi ön planda tutan, açık iletişim ve yapıc1 görüşmeye önem veren, yöneticilerinin daha çok liderlik rolü oynadıkları yapılar olarak kendilerini değiştirmelidirler (Bozkurt, 2003, s. 60). Okulların öğrenen örgüt olması için geçmişteki deneyimlerinden elde ettikleri bilgileri günümüze uyarlamaları, yeni öğrenme yolları keşfedebilmeleri ve sorunlara beraber çözüm yolu bulmaları ile gerçekleşmektedir. Okuldaki öğretmenler, çalışanlar, öğrenciler görüş ve düşüncelerini açıkça ifade etmekten çekindiklerinde ve örgütsel sessizlik davranışını gösterdiklerinde de okulda öğrenme oluşumu da bundan olumsuz etkilenecektir. Bunun yanında örgütsel öğrenmenin hâkim olduğu okullarda, okul çalışanları düşüncelerini özgürce ifade edebilmektedirler. Bu nedenle okulların gelişmelere uyum sağlayarak yaşamlarını devam ettirebilmeleri için örgütte tüm çalışanlarla birlikte sürekli öğrenme anlayışını olması ve uygulanması gerekmektedir (Çakır, 2019, s. 57; Memduoğlu ve Kuşçi, 2012, s. 751).Bu bağlamda örgütsel öğrenme ile örgütsel sessizlik kavramı arasında bir ilişki olduğu öngörülebilmektedir. Öğrenen bir örgütte çalışanların memnuniyet düzeyinin yüksek olduğu, daha umutlu oldukları, fikirlerini paylaşmak için ortam buldukları, her çalışanın görüşünün değerlendirmeye alındığı, motive edici bir ortam oluştuğu, çalışanlarının potansiyellerinin ortaya çıkarıldığı, çalışanların geliştirildiği ve desteklendiği görülmektedir (Keskin, 2007, s. 73; Töremen, 2001, s. 45). Dolayısı ile örgütsel öğrenmenin yüksek olduğu okullarda çalısanların öğretmenlerin örgütsel sessizlik düzeylerinin de düşük olabileceği düşünülebilmektedir. Bu amaçla araştırmada okulların örgütsel öğrenmeleri ile öğretmenlerin örgütsel sessizlik düzeyleri arasındaki ortaya konulmaya çalısıılmaktadır. Bu amaçla araştırmada aşağıdaki sorulara cevap aranmıştır.

1. Öğretmenlere göre okullarda örgütsel öğrenme ne düzeydedir? Okullardaki örgütsel öğrenme düzeyine yönelik öğretmen algıları çalıştıkları okul düzeyine göre anlamlı olarak farklılaşmakta midir?

2. Öğretmenlerin örgütsel sessizlik düzeyleri nedir? Öğretmenlerin örgütsel sessizlik düzeyleri çalştıkları okul düzeyine göre farklıllk göstermekte midir?

3. Okulların örgütsel öğrenme düzeyi ile öğretmenlerin örgütsel sessizlik düzeyleri arasında bir ilişki var midir?

4. Okullardaki örgütsel öğrenme uygulamaları, öğretmenlerin örgütsel sessizlik davranışlarını yordamakta midır?

\section{Yöntem}

Bu bölümde araştırmanın modeline, evren ve örneklemine, verilerin toplanması ve çözümlenmesine ilişkin bilgilere yer verilmiştir.

\section{Araştırmanın Modeli}

$\mathrm{Bu}$ araştırma okulların örgütsel öğrenme düzeyleri öğretmenlerin örgütsel sessizlikleri arasındaki ilişkiyi belirlemeyi amaçlayan araştırma ilişkisel tarama modelindedir. İlişkisel tarama modeli, iki ve daha çok sayıdaki değişken arasında birlikte değişim olup olmadığını ve değişimin derecesini belirlemeyi amaçlamaktadır (Karasar, 2009, s. 81).

\section{Evren ve Örneklem}

Araştırmanın evreni 2019-2020 eğitim öğretim yılında Kütahya'nın Gediz ilçesindeki ilkokul, ortaokul ve liselerde görev yapan 610 öğretmen oluşturmaktadır. Örneklem seçiminde kuramsal örneklem büyüklüğü çizelgesinden yararlanılmıştır. Çizelgede 1000 kişilik evrende $\% 95$ 'lik güven düzeyi, $\alpha=.05$ anlamlılık ve \% 5'lik hoşgörü düzeyi için gerekli örneklem büyüklüğü 277 kişi olarak belirtilmiştir. Ancak araştırmada güven düzeyini artırmak için 404 ölçek uygulanmıştır (Balc1, 2011, s. 105). Bu nedenle araştırmanın örneklemini Kütahya'nın Gediz ilçesinde görev yapan 404 öğretmen oluşturmaktadır. Araştırmada ulaşım zorluğu ve maliyet nedeniyle kolay ulaşılabilir örnekleme yoluna gidilmiştir. Ölçekler araştırmacı tarafindan ulaşılabilen okullardaki öğretmenlere uygulanmıştır. Toplanan ölçeklerin incelenmesi sonucunda hiçbir ölçek geçersiz görülmediğinden elenmemiştir.

\section{Örnekleme İlişkin Demografik Veriler}

Örneklemi oluşturan öğretmenlerin cinsiyet, kıdem, aynı okuldaki çalışma süreleri, okuldaki öğretmen sayısı ve okul düzeyi özelliklerine ilişkin bilgiler Tablo 1'de yer almaktadır. 
Tablo 1. Örnekleme Ilişkin Demografik. Bilgiler

\begin{tabular}{llll}
\hline Demografik Özellikler & & Say1 & Yüzde \\
\hline \multirow{2}{*}{ Cinsiyet } & Kadın & 172 & 42,6 \\
& Erkek & 232 & 57,4 \\
\hline \multirow{2}{*}{ Kıdem } & $1-10$ Yıl & 168 & 41,6 \\
& $11-20$ Yıl & 136 & 33,7 \\
\hline \multirow{2}{*}{ Okuldaki Öğretmen Sayısı } & 21 Yıl ve Üzeri & 100 & 24,7 \\
\hline \multirow{2}{*}{ Çalşsılan Okul Düzeyi } & 1-20 Kişi & 251 & 62,1 \\
& 21 ve Üzeri Kişi & 133 & 37,9 \\
\hline
\end{tabular}

Tablo 1 incelendiğinde araştırmaya katılan öğretmenlerin cinsiyetlerine göre 172' sinin (\%42,6) kadın, 232 'sinin $(\% 57,4)$ erkek olduğu görülmektedir. Kıdeme göre, kıdemi 1-10 yll olan öğretmen sayıs1 168 (\%41,6), 11-20 yll olan öğretmen sayısı $136(\% 33,7)$ ve 21 yll ve üzeri olan öğretmen sayısı $100(\% 24,7)$ olarak tespit edilmiştir. Buna göre örneklemin neredeyse yarısının mesleklerinin ilk 10 yılını tamamlamayan öğretmenler olduğu tespit edilmiştir. Öğretmenlerin okullarında çalışan öğretmen sayısına göre, okulda çalş̧an öğretmen sayıs1 1-20 öğretmen olan öğretmen sayıs1 251, oran1 \%62,1; 21 ve üzeri öğretmen sayıs1 133, oranı \% 37,9'dur. Çalışılan okul düzeyine göre, çalıştığı okul düzeyi ilkokul olan öğretmen sayısı 157( $\% 38,9)$ çalıştığı okul düzeyi ortaokul olan öğretmen sayıs1 $137(\% 33,9)$, çalsştığı okul düzeyi lise olan öğretmen sayıs $110(\% 27,2)$ olarak tespit edilmiştir.

\section{Veri Toplama Araçları}

Araştırmada veriler Örgütsel Öğrenme Ölçeği ve “Öğretmenler İçin Örgütsel Sessizlik Ölçeği” ile toplanmıştır. Ölçeklere ilişkin açılamalar aşağıdaki şekildedir.

Örgütsel Öğrenme Ölçeği Yavaş (2012, s. 99) tarafindan geliştirilmiştir. Örgütsel Öğrenme Ölçeği, Likert tipi bir veri toplama aracı olup maddeler: “(1) Hiç bir zaman ile (5) Her zaman” arasında 5'li olarak derecelendirilmiştir. Ölçeğin güvenirlik analizlerinde, Alpha Güvenilirlik katsayıları sürekli öğrenme boyutu için .85, bilişsel süreçler boyutu için .74, şeffaflık boyutu için .85 ve soruna yönelik olma boyutu için ise .79 olarak hesaplanmıştır. Yavaş( 2012, s.103) tarafindan ölçeğin boyutlara göre güvenilirlik katsayıları da .71 ile .83 arasında değişmektedir. Ölçeğin yapılan doğrulayıcı faktör analizi sonuçlarına göre de $\mathrm{X}^{2} / \mathrm{df}=2.910$, RMSEA $=0.069$, CFI $=0.887$, GFI $=0.867$, AGFI $=00.835$, AIC $=889.454<1955$ ve $\mathrm{CAIC}=1199.542<3940$ olmak üzere uyum iyiliği indeksi değerlerinin istenilen düzeyde olması nedeniyle ölçeğin doğrulandı̆̆1 görülmüsstür (Büyüköztürk, 2012, s. 271-272)

Örgütsel Sessizlik Ölçeği ise, Kahveci ve Demirtaş (2013, s. 167) tarafindan geliştirilmiştir. Likert tipi olan veri toplama aracinda maddeler: "(1) Hiç katılmıyorum ile (5) Tamamen katıllyorum” arasında 5'li olarak derecelendirilmiştir. Ölçeğin boyutlarına ilişkin Alpha güvenilirlik katsayılarına bakıldığında; okul ortamı boyutu için. 79 , duygu boyutu için .74, sessizliğin kaynağ1 boyutu için .80 , yönetici boyutu için .79 ve izolasyon boyutu için ise .83 olduğu görülmüsstür. Kahveci ve Demirtaş (2013, s.178) tarafindan hesaplanan ölçeğin boyutlara göre güvenilirlik katsayıları da .74 ile .88 arasındadır. Ölçeğin yapılan faktör analizi sonuçlarına göre de $\mathrm{X}^{2} / \mathrm{df}=4.026$, RMSEA $=0.087, \mathrm{CFI}=0.915, \mathrm{GFI}=0.887$, AGFI $=0.838$, AIC $=583.066<1955$ ve CAIC $=843.140<3940$ olmak üzere uyum iyiliği indeksi değerlerinin istenilen düzeyde olması nedeniyle ölçeğin doğrulandığı görülmüştür (Büyüköztürk, 2012, s. 271-272).

\section{Verilerin Analizi}

Verilere hangi tür analizlerin yapılması gerektiğini tespit etmek için, verilerin normal dağılıp dağılmadığına yönelik çarpıklık ve basıklık katsayılarına bakılmıştır. Okullarda "Örgütsel Öğrenme Ölçeği" ve "Öğretmenler İçin Örgütsel Sessizlik Ölçeği" ile toplanan veriler üzerinde yapılan analizler sonucunda hesaplanan çarpıklık ve basıklık katsayısı verilerin normal dağıldığını göstermektedir (Bursal, 2017, s. 43). Tablo 2' de verilerin çarpıklık basıklık testi sonuçları görülmektedir. 
Tablo 2. Araștrma Verilerinin Normallik Dă̆ğlım Durumuna İlişkin Veriler

\begin{tabular}{lll}
\hline Boyutlar & Çarpıklık & Basıklık \\
\hline Sürekli Öğrenme &,- 207 &,- 370 \\
Bilişsel Süreçler &,- 714 &,- 023 \\
Şeffaflık &,- 892 &, 747 \\
Soruna Yönelik Olma &,- 501 &, 307 \\
Örgütsel Öğrenme Toplam &,- 394 &,- 307 \\
\hline Okul Ortamı &, 483 &,- 677 \\
Duygu &,- 075 &,- 652 \\
Sessizliğin Kaynağı &, 389 &,- 739 \\
Yönetici &, 174 & $-1,322$ \\
İzolasyon &, 209 & $-1,138$ \\
Örgütsel Sessizlik Toplam &, 046 & $-1,050$ \\
\hline
\end{tabular}

Tablo 2'ye göre elde edilen verilerin istenen değerler arasında olması sebebiyle analizlerde Tek yönlü varyans analizi (ANOVA), Pearson Momentler Çarpımı Korelasyonu ve çoklu regresyon analizi teknikleri kullanılmıştır.

Okulların örgütsel ögrenmesi ile öğretmenlerin örgütsel sessizlik düzeylerine öğretmen algilarının görev yapılan okul düzeyi değişkenine göre anlamlı farkllık sergileyip sergilemediğini belirlemek için ANOVA kullanılmıştır. Farkın anlamlı olduğu boyutlarda, anlamlı farkın hangi grup veya gruplardan kaynaklandığını belirlemek için varyansların eşit olması nedeniyle TUKEY HSD testi yapılmış, anlamlılık düzeyi 05 olarak alınmıştır. Okulların örgütsel öğrenmeleri ile öğretmenlerin örgütsel sessizlik düzeyleri arasında anlamlı bir ilişkinin olup olmadığını tespit etmek için ise Pearson Momentler Çarpımı Korelasyonu kullanılmıștır. Yapılan analizlerde anlamlıık düzeyi 0.05 olarak alınmıștır Bunun yanında araştırma değişkenleri arasında çoklu bağlantıllılık probleminin olup olmadığını belirlemek için VIF ve tolerans değerleri incelenmiştir. VIF değerlerinin 1.423 ile 2.605arasında bulunduğu tolerans değerlerinin de .384 ile .703 arasında olduğu sonucuna ulaşılmıştır. Tolerans değerlerinin.02'den büyük, VIF değerlerinin ise 10 'dan küçük olduğunun tespit edilmesi nedeniyle çoklu bağlantılllık problemi olmadığ1 görülmüştür (Seçer, 2013, s. 108). Okulların örgütsel öğrenme düzeyleri ile öğretmenlerin örgütsel sessizliklerini yordayıp yordamadığına yönelik olarak da çoklu regresyon analizi yapılmışır.

\section{Bulgular}

Bu bölümde; araştırmanın temel problemi ve alt problemlerine cevap bulmak için yapılan araștırma araştırma sonucunda elde edilen verilerle ulaşılan bulgular ve yorumlara yer verilmiştir. Öğretmenlerin okullardaki örgütsel öğrenme uygulamalanı alg1 düzeyleri aşağıda Tablo 3’te görülmektedir.

Tablo 3. Öğretmenlerin Okullarda Örg̈̈tsel Öğrenmeye İliskin Algz Düreyleri

\begin{tabular}{lccc}
\hline Değişkenler & Ortalama $(\bar{X})$ & Standart Sapma(Ss) & Düzey \\
\hline Sürekli Öğrenme & 3,50 &, 67909 & Yüksek \\
Şeffaflık & 4,08 &, 68848 & Yüksek \\
Bilişsel Süreçler & 4,19 &, 64100 & Yüksek \\
Soruna Yönelik Olma & 3,83 &, 69619 & Yüksek \\
Örgütsel Öğrenme & 3,86 &, 54734 & Yüksek \\
\hline
\end{tabular}

Tablo 3 incelendiğinde, öğretmenlerin okullarda örgütsel öğrenme uygulamalarına yönelik alg1 düzeyleri, sürekli öğrenme $(\bar{X}=3,50)$, şeffaflık $(\bar{X}=4,08)$,bilişsel süreçler $(\bar{X}=4,19)$, soruna yönelik olma $(\bar{X}=3,83)$ boyutlarında yüksektir. Örgütsel öğrenme uygulamaların genel olarak var olma düzeyine yönelik öğretmen algılarının da $(\bar{X}=3,86)$ yüksek düzeyde olduğu görülmektedir. Tablo 4 'te ise, çalısılan okul düzeyi değişkenine göre öğretmenlerin okullarda örgütsel öğrenme düzeyine yönelik algılarına ilişkin ilişkin bulgular yer almaktadır. 
Tablo 4. Callšllan Okul Düreyi Değğskenine Göre Ögrretmenlerin Okullarda Örgütsel Ögrrenme Dǚreyine Yönelik Algilarna İliskin ANOV A Testi Sonuclar

\begin{tabular}{|c|c|c|c|c|c|c|c|c|c|c|c|}
\hline $\begin{array}{l}\text { Örgütsel } \\
\text { Öğrenme }\end{array}$ & $\begin{array}{l}\text { Okul } \\
\text { Düzey }\end{array}$ & $\overline{\mathbf{N}}$ & $\bar{X}$ & Ss & Var. K & $\overline{\mathrm{KT}}$ & $\overline{S d}$ & KO & $\bar{F}$ & $\bar{p}$ & Fark \\
\hline \multirow{3}{*}{$\begin{array}{l}\text { Sürekli } \\
\text { Öğrenme }\end{array}$} & İlkokul & 157 & 3,65 & 66058 & G.Aras1 & 5,752 & 2 & 2,876 & \multirow[t]{3}{*}{6,403} & \multirow[t]{3}{*}{, 002} & $1-2$ \\
\hline & Ortaokul & 137 & 3,43 & 68907 & G.İçi Top. & 180,098 & 401 & ,449 & & & $1-3$ \\
\hline & Lise & 110 & 3,38 & 65979 & & 185,849 & 403 & & & & \\
\hline \multirow{3}{*}{ Şeffaflık } & İlkokul & 157 & 4,22 & ,61249 & G.Aras1 & 7,286 & 2 & 3,643 & \multirow[t]{3}{*}{7,951} & \multirow[t]{3}{*}{,000 } & $1-3$ \\
\hline & Ortaokul & 137 & 4,09 &, 70652 & G.İçi Top. & 183,738 & 401 &, 458 & & & $2-3$ \\
\hline & Lise & 110 & 3,88 &, 72523 & & 191,024 & 403 & & & & \\
\hline \multirow{3}{*}{$\begin{array}{l}\text { Bilişsel } \\
\text { Süreçler }\end{array}$} & İlkokul & 157 & 4,34 & 58023 & G.Aras1 & 6,755 & 2 & 3,378 & \multirow[t]{3}{*}{8,528} & \multirow[t]{3}{*}{,000 } & $1-2$ \\
\hline & Ortaokul & 137 & 4,15 & ,64352 & G.İçi Top. & 158,830 & 401 & ,396 & & & $1-3$ \\
\hline & Lise & 110 & 4,03 & 67721 & & 165,585 & 403 & & & & \\
\hline \multirow{3}{*}{$\begin{array}{l}\text { Soruna } \\
\text { Yönelik Olma }\end{array}$} & İlkokul & 157 & 3,99 & ,64950 & G.Aras1 & 7,036 & 2 & 3,518 & \multirow[t]{3}{*}{7,492} & \multirow[t]{3}{*}{,001 } & $1-2$ \\
\hline & Ortaokul & 137 & 3,75 & 74537 & G.İçi Top. & 188,290 & 401 &, 470 & & & $1-3$ \\
\hline & Lise & 110 & 3,69 & ,65611 & & 195,326 & 403 & & & & \\
\hline
\end{tabular}

Tablo 4'e göre, öğretmenlerin okullarda örgütsel öğrenmenin sürekli öğrenme $\left[\mathrm{F}_{(2-401)}=6,403\right.$; $\mathrm{p}<0.05]$, şeffaflık $\left[\mathrm{F}_{(2-401)}=7,951 ; \mathrm{p}<0.05\right]$ ve soruna yönelik olma $[\mathrm{F}(2-401)=7,492 ; \mathrm{p}<0.05]$ boyutlarının gerçekleşme düzeyine yönelik algılarının çalışılan okul düzeyi değişkenine göre farklılaşıp farklılaşmadığını belirlemek için uygulanan tek yönlü varyans analizi sonucunda puan ortalamaları arasında istatistiksel olarak anlamlı bir farklılık tespit edilmiştir Anlamlı farklılıklar ilkokul öğretmenleri ile ortaokul öğretmenleri ve lise öğretmenleri arasındadır. Elde edilen bulgulara göre ilkokul öğretmenlerinin diğer okul düzeylerine göre, okullarında örgütsel öğrenmenin daha yüksek düzeyde gerçekleştiğini düşündükleri görülmektedir. Tablo 5 'te öğretmenlerin örgütsel sessizlik düzeylerine ilişkin bulgular görülmektedir.

Tablo 5. Ögrretmenlerin Okullarda Örgütsel Sessizllik. Düzeyine Ilişkin Algz Düzeyleri

\begin{tabular}{lccc}
\hline Değişkenler & Ortalama $(\bar{X})$ & Standart Sapma(Ss) & Düzey \\
\hline Okul Ortam1 & 2,04 &, 79212 & Düşük \\
Duygu & 2,95 & 1,05257 & Orta \\
Sessizlik Kaynağ1 & 2,29 &, 95207 & Düşük \\
Yönetici & 2,70 & 1,36872 & Orta \\
İzolasyon & 2,62 & 1,24180 & Orta \\
Örgütsel Sessizlik & 2,47 &, 86286 & Düşük \\
\hline
\end{tabular}

Tablo 5'ten anlaşılacağı üzere genel olarak öğretmenlerin örgütsel sessizlik algılarının $(\bar{X}=2,47)$ düşük düzeyde olduğu görülmektedir. Okul $\operatorname{ortam} 1(\bar{X}=2,04)$, sessizlik kaynağı $(\bar{X}=2,29)$ boyutlarnna yönelik algıların "düşük", duygu $(\bar{X}=2,95)$, yönetici $(\bar{X}=2,70)$ ve izolasyon $(\bar{X}=2,62)$ boyutlarına yönelik alg1ların ise "orta" düzeyde olduğu görülmektedir. Tablo 6 'da öğretmenlerin örgütsel sessizlik düzeylerinin çalssılan okul düzeyi değişkenine göre incelenmesine yönelik bulgulara yer verilmiştir.

Tablo 6. Calşsllan Okul Düreyi Değişkenine Öğretmenlerin Örgütsel Sessizlik Düzeyine Yönelik. ANOV A Testi Sonuçar

\begin{tabular}{|c|c|c|c|c|c|c|c|c|c|c|c|}
\hline $\begin{array}{l}\text { Örgütsel } \\
\text { Sessizlik }\end{array}$ & $\begin{array}{c}\text { Okul } \\
\text { Düzey }\end{array}$ & $\mathbf{N}$ & $\bar{X}$ & Ss & Var. K & $\mathbf{K} \mathbf{T}$ & Sd & KO & $\mathbf{F}$ & $\mathrm{p}$ & Fark \\
\hline \multirow{3}{*}{$\begin{array}{l}\text { Okul } \\
\text { Ortamı }\end{array}$} & $\overline{\text { İlkokul (1) }}$ & 157 & 1,94 &, 81236 & G.Aras1 & 8,059 & 2 & 4,030 & 6,601 &, 002 & $1-3$ \\
\hline & Ortaokul(2) & 137 & 1,97 &, 74624 & G.İçi Top. & 244,804 & 401 & ,610 & & & $2-3$ \\
\hline & Lise (3) & 110 & 2,27 &, 77884 & & 252,863 & 403 & & & & \\
\hline \multirow{3}{*}{ Duygu } & İlkokul (1) & 157 & 2,78 & 1,05361 & G.Aras1 & 11,850 & 2 & 5,925 & 5,467 &, 005 & $1-3$ \\
\hline & Ortaokul(2) & 137 & 2,92 & 1,07785 & G.İçi Top. & 434,637 & 401 & 1,084 & & & \\
\hline & Lise (3) & 110 & 3,21 & ,97427 & & 446,487 & 403 & & & & \\
\hline \multirow{3}{*}{$\begin{array}{l}\text { Sessizliğin } \\
\text { Kaynağı }\end{array}$} & İlkokul (1) & 157 & 2,15 & 1,01282 & G.Aras1 & 5,643 & 2 & 2,822 & 3,146 &, 044 & $1-3$ \\
\hline & Ortaokul(2) & 137 & 2,32 &, 89717 & G.İçi Top. & 359,648 & 401 & ,897 & & & \\
\hline & Lise (3) & 110 & 2,44 & 90945 & & 365,291 & 403 & & & & \\
\hline \multirow{3}{*}{ Yönetici } & İlkokul (1) & 157 & 2,59 & 1,38918 & G.Aras1 & 3,666 & 2 & 1,833 & ,978 & ,377 & Yok \\
\hline & Ortaokul(2) & 137 & 2,82 & 1,42460 & G.İçi Top. & 751,316 & 401 & 1,874 & & & \\
\hline & Lise (3) & 110 & 2,69 & 1,26437 & & 754,982 & 403 & & & & \\
\hline \multirow{3}{*}{ İzolasyon } & İlkokul (1) & 157 & 2,30 & 1,20527 & G.Aras1 & 29,907 & 2 & 14,953 & 10,137 & 000 & $1-2$ \\
\hline & Ortaokul(2) & 137 & 2,75 & 1,22385 & G.İçi Top. & 591,549 & 401 & 1,475 & & & $1-3$ \\
\hline & Lise (3) & 110 & 2,94 & 1,21621 & & 621,456 & 403 & & & & \\
\hline
\end{tabular}


Tablo 6 da görüleceği gibi, öğretmenlerin örgütsel sessizlik boyutlarından okul ortamı $\left[\mathrm{F}_{(2-401)}=6,601\right.$; $\mathrm{p}<0.05]$ puan ortalamaları arasında istatistiksel olarak anlamlı bir farklılık bulunmuştur. Bu farklılık ilkokul öğretmenleri ile lise öğretmenleri ve ortaokul öğretmenleri ile lise öğretmenleri arasındadır. Buna göre ilkokul öğretmenlerinin örgütsel sessizliğin okul ortamı boyutuna yönelik algıları, lise öğretmenlerine göre daha düşüktür. Yine ortaokul öğretmenlerinin lise öğretmenlerine göre okul ortamı boyutuna ilişkin algilarının daha düşüktür. Öğretmenlerin örgütsel sessizlik boyutlarından duygu $\left[\mathrm{F}_{(2-401)}=5,467 ; \mathrm{p}<0.05\right]$ ve sessizliğin kaynağ1 $\left[\mathrm{F}_{(2-342)}=3,146 ; \mathrm{p}<0.05\right]$ boyutlarına yönelik algılarının da çalışılan okul düzeyi değişkenine göre farklılaştığı görülmektedir. Bu boyutlarda farklılık ilkokul öğretmenleri ile lise öğretmenleri arasındadır. İlkokul öğretmenlerinin örgütsel sessizlik alg1lan lise öğretmenlerine göre daha düşüktür. Bununla birlikte öğretmenlerin örgütsel sessizliğin yönetici boyutuna yönelik algilarının çalışlan okul düzeyi değişkenine göre farklılaşmamaktadır $\left[\mathrm{F}_{(2-401)}=, 978 ; \mathrm{p}>0.05\right]$. Öğretmenlerin örgütsel sessizliğin izolasyon boyutuna yönelik algılarının da okul düzeyi değişkenine göre farklılık gösterdiği anlaşılmaktadır $\left[\mathrm{F}_{(2-401)}=10,137 ; \mathrm{p}<0.05\right]$. Buna göre ilkokul öğretmenlerinin ortaokul ve lise öğretmenlerine göre ilişkin alg1ları daha düşüktür. Tablo 7'de öğretmenlerin okullarda örgütsel öğrenmeye yönelik alg1ları ile örgütsel sessizlik düzeyleri arasındaki ilişkilerin belirlenmesine yönelik korelasyon analizi sonuçları yer almaktadır.

Tablo 7. Okullarda Örgütsel Öğrenme Profillerine Yönelik Algzlar İle Ögrretmenlerin Örgütsel Sessizllik Düzeyleri Arasindaki Iliskivi Gösteren Korelasyon Analizi Tablosu

\begin{tabular}{|c|c|c|c|c|c|c|}
\hline $\begin{array}{l}\text { Örgütsel Sessizlik } \\
\text { Öğrenme }\end{array}$ & $\begin{array}{c}\text { Okul } \\
\text { Ortamı }\end{array}$ & Duygu & $\begin{array}{l}\text { Sessizliğin } \\
\text { Kaynağı }\end{array}$ & Yönetici & İzolasyon & $\begin{array}{l}\text { Örgütsel } \\
\text { Sessizlik }\end{array}$ \\
\hline Sürekli Öğrenme &,$- 460 * *$ &,$- 390 * *$ &,$- 219 * *$ &,$- 128^{* *}$ &,$- 274 * *$ &,$- 340 * *$ \\
\hline Şeffaflık &,$- 608 * *$ &,$- 376 * *$ &,$- 435^{* *}$ &,$- 347 * *$ &,$- 414^{* *}$ &,$- 525^{* *}$ \\
\hline Bilişsel Süreçler &,$- 488^{* *}$ &,$- 298 * *$ &,$- 307 * *$ &,$- 178^{* *}$ &,$- 281 * *$ &,$- 369 * *$ \\
\hline Soruna Yönelik Olma &,$- 586 * *$ &,$- 446 * *$ &,$- 370 * *$ &,$- 223 * *$ &,$- 334 * *$ &,$- 463 * *$ \\
\hline Örgütsel Öğrenme &,$- 646 * *$ &,$- 462 * *$ &,$- 390 * *$ &,$- 257 * *$ &,$- 394 * *$ &,$- 508 * *$ \\
\hline
\end{tabular}

*0,05 düzeyinde anlamlıdır.**0,01 düzeyinde anlamlıdır.

Tablo 7'den anlaşılacağ1 üzere, öğretmenlerin okullardaki örgütsel öğrenme düzeyine yönelik alg1lar1 ile örgütsel sessizlik boyutlarından " okul ortamı ( $\mathrm{r}=-$-,646), duygu $(\mathrm{r}=-, 462)$, sessizliğin kaynağı $(\mathrm{r}=-, 390)$, izolasyon ( $\mathrm{r}=-$-394) boyutlarına yönelik algiları arasında anlamlı negatif yönlü orta düzeyde bir korelasyon ilişkisi tespit edilmiştir. Ayrıca öğretmenlerin örgütsel öğrenme düzeyine yönelik algıları ile örgütsel sessizlik düzeylerinden yönetici boyutuna $(\mathrm{r}=-, 257)$ yönelik algıları arasında ise anlamlı negatif yönlü düşük düzeyde bir ilişki tespit edilmiştir. Bununla birlikte öğretmenlerin okulların örgütsel öğrenme düzeyine yönelik alg1ları ile örgütsel sessizlik düzeyleri arasında $(\mathrm{r}=-$-,508) anlamlı negatif yönlü orta düzeyde bir ilişki tespit edilmiştir. Tablo 8'de okullarda örgütsel öğrenme algilarının öğretmenlerin örgütsel sessizlik düzeylerini yordama durumuna ilişki bulgular yer almaktadır

Tablo 8. Okullarda Örgütsel Ögrrenme Algılarmm Ögrretmenlerin Örgütsel Sessiə̨lik Dǚeylerini Yordama Durumuna İliskin Regresyon Analizi Sonuclar

\begin{tabular}{|c|c|c|c|c|c|c|c|}
\hline \multicolumn{8}{|c|}{ Yordanan Değişken: Örgütsel Sessizlik } \\
\hline Yordayı1 Değişken & $\bar{B}$ & S. Hata & $\overline{\beta \text { (Beta) }}$ & $\bar{t}$ & $\bar{p}$ & Kismi & İkili \\
\hline Sabit & 5,959 & .288 & & 20,664 & .000 & & \\
\hline Sürekli Öğrenme & -.081 & .079 & -.063 & $-1,027$ & .305 &,- 051 & -.043 \\
\hline Şeffaflık & -.503 & .063 & -.387 & -7.974 & .000 & -.371 & -.331 \\
\hline Bilişsel Süreçler & -.070 & .087 & -.050 & -.803 & .422 & -.040 & -.033 \\
\hline Soruna Yönelik Olma & -.222 & .084 & -.173 & $-2,645$ & .008 & -.131 & -.110 \\
\hline $\mathrm{R}^{2}=.314$ & & & $(4-04)=45$ & & & $\mathrm{P}=.000$ & \\
\hline
\end{tabular}

Yapılan regresyon analizi sonucunda, öğretmenlerin okullarda örgütsel öğrenme uygulamalarına yönelik şeffaflık ve soruna yönelik olma algılarının örgütsel sessizlik düzeylerini anlamlı bir şekilde yordadığ1 sonucuna ulaşılmıştır. $(\mathrm{R}=.560, \mathrm{R} 2=.314, \mathrm{p}<.05)$. Öğretmenlerin algılarına göre okullardaki örgütsel öğrenme uygulamalarının şeffaflık ve soruna yönelik olma boyutlarının var olma düzeyi öğretmenlerin örgütsel sessizliklerinin yaklaşı \%31' ini açıklamaktadır. Yapılan regresyon analizinin t değerleri incelendiğinde; örgütsel öğrenmenin şeffaflık boyutundaki bir birimlik artışın örgütsel sessizlik sabit değişkeni üzerinde -.503'lük bir azalmaya, soruna yönelik olma boyutundaki bir birimlik artışın örgütsel sessizlik sabit değişkeni üzerinde -.222'lik azalmaya neden olduğu anlaşılmaktadır. Öğretmenlerin alg1larına göre sürekli öğrenme ve bilişsel süreçler boyutları ise öğretmenlerin örgütsel sessizliklerini yordamamaktadır. Bununla ilgili kurulabilecek regresyon denklemi aşağıdaki şekildedir. 
Örgütsel sessizlik $=5,959-0,503 *$ Şeffaflık-0,222*Soruna yönelik olma

\section{Tartışma, Sonuç ve Öneriler}

Bu araştırma, okullarda örgütsel öğrenmeleri ile öğretmenlerin örgütsel sessizlik düzeyleri arasındaki ilişkiyi belirlemek amacıyla yapılmıştır. Araştırma sonuçlarına göre öğretmenlerin okullarda örgütsel öğrenmeye yönelik sürekli öğrenme, şeffaflık, bilişsel süreçler, soruna yönelik olma algı düzeylerinin yüksek olduğu görülmektedir. Araştırmada örgütsel öğrenme uygulamalarının okullarda genel olarak gerçekleşme düzeyine yönelik öğretmen algılarının da yüksek düzeyde olduğu anlaşılmaktadır. Ay Işık (2017, s. 67) ve Çakır (2019, s. 119)araştırmalarında, öğretmenlerin okullarında örgütsel öğrenme düzeylerini yüksek düzeyde olduğu sonucuna ulaşmışlardır. Yine Bilir ve Arslan (2016, s. 248) tarafindan yapılan araştırmada da öğretmenlerin kendi okullarına ilişkin öğrenen örgüt algılarının "iyi”" düzeyde olduğu belirlenmiştir. Bahsedilen araştırmalarla bu araştırma sonuçlarının benzer olduğu görülmektedir. Alanoğlu (2014, s. 155) ve Zengin ve Gündüz $(2018$, s. 70$)$ ise, araştırmalarında öğretmenlerin okullardaki örgütsel öğrenme düzeyini orta düzeyde gördüklerini bulmuşlardır

Öğretmenlerin örgütsel öğrenmeye yönelik algıları arasında çalıştıkları okul düzeyi değişkenine göre, anlamlı bir farklılık bulunmuştur. Örgütsel öğrenmenin sürekli öğrenme boyutundaki anlamlı farklılıklar ilkokul öğretmenleri ile ortaokul öğretmenleri ve lise öğretmenleri arasındadır. Elde edilen sonuçlara göre ilkokul öğretmenlerinin diğer okul düzeylerine göre, okullarında örgütsel öğrenmenin sürekli öğrenme boyutunun daha yüksek düzeyde gerekleştiğini düşünmektedirler. Bunun sebebi olarak da ortaokul ve lise ögretmenlerinin branş öğretmenleri olması ve farklı günlerde, saatlerde okulda bulunmaları nedeniyle ilkokul öğretmenlerine göre birlikte daha az vakit geçirmeleri nedeniyle paylaşımlarının az olması ile beraber daha az öğrenme faaliyetlerinde bulunamamaları gösterilebilir. Örgütsel öğrenmenin şeffaflık boyutunda da anlamlı farkll1ıklar ilkokul öğretmenleri ile lise öğretmenleri ve ortaokul öğretmenleri ile lise öğretmenleri arasındadır. Buna göre ilkokul öğretmenleri örgütsel öğrenmenin şeffaflık boyutunun okullarda daha yüksek olduğunu düşünmektedir. Sınıf öğretmenleri olmaları sebebiyle sürekli hem okul yöneticileriyle hem de birbirleriyle daha fazla vakit geçirmeleri birbirlerine karşı duydukları güveni artırıyor olabilir. Ortaokul öğretmenlerinin lise öğretmenlerine göre şeffaflık düzeyinin yüksek olmasının sebebi olarak çoğu ilkokul ve ortaokulun beraber aynı binada eğitim öğretime devam etmesi nedeniyle benzer özellikler göstermeleri olarak açklanabilir. Örgütsel öğrenmenin bilişsel süreçler boyutunda anlamlı farklılıklar ilkokul öğretmenleri ile ortaokul ögretmenleri ve lise öğretmenleri arasındadır. Yine ilkokul ögretmenlerinin diğer okul düzeylerine göre örgütsel öğrenmenin bilişsel süreçler boyutuna ilişkin algılarının daha yüksek olduğu görülmektedir. Bunun sebebi olarak da ilkokul öğretmenlerinin evrak düzeninde ortaokul ve lise öğretmenlerine göre daha titiz davrandıkları yorumunda bulunulabilir. Soruna yönelik olma boyutunda anlamlı farklilıklar ilkokul öğretmenleri ile ortaokul öğretmenleri ve ilkokul öğretmenleri ile lise öğretmenleri arasındadır. İlkokul öğretmenlerinin diğer okul düzeylerine göre örgütsel öğrenmenin soruna yönelik olma boyutuna ilişkin algılarının daha yüksek olduğu görülmektedir. Bunun sebebi olarak da ilkokul öğretmenlerinin okullarda daha çok zaman geçirdiklerinden dolayı okul daha iyi tanıdıklarından sorundan çok çözüme odaklı bir anlayışa sahip oldukları düşünülebilir. Uysal (2008, s. 85) bu araştırma sonuçlarıyla aynı doğrultuda ilkokul öğretmenlerinin, branş öğretmenlerine göre okullarının daha yüksek örgütsel öğrenme düzeyine sahip olduğunu düşündüklerini tespit etmiştir. Ünal da (2014, s. 29) araştırmasında öğretmen görüşlerine göre ilköğretim okullarında, ortaöğretim okullarına göre örgütsel öğrenme düzeyinin daha yüksek olduğunu bulmuştur. Bahsedilen araştırma sonuçları da araştırmayı destekler niteliktedir.

Araştırmanın diğer değişkenin ilişkin sonuçları bakıldığında ise, öğretmenlerin okullarda örgütsel sessizliğe yönelik, okul ortamı ve sessizliğin kaynağı boyutlarına yönelik alg1 düzeylerinin düşük olduğu görülmektedir. Öğretmenlerin örgütsel sessizliğin duygu, yönetici ve izolasyon boyutlarına yönelik algıları da orta düzeydedir. Araştırmada genel olarak örgütsel sessizlik düzeyine yönelik öğretmen algılarının düşük düzeyde olmakla birlikte; örgütsel sessizliğinin bazı boyutlarında düşük bazı boyutlarında ise orta düzeyde olduğu anlaşılmaktadır. Bu araştırmayı destekler şekilde Önder (2017, s. 674) de öğretmenlerin sessizlik düzeylerini düşük bulmuştur. Ünlü, Hamedoğlu ve Yaman (2015, s. 145), Yörür (2016, s. 75), Dal (2017, s. 79) Kahveci ve Demirtaş (2013, s. 57) ve Nartgün ve Kartal'ın (2013, s. 61) araştırmalarında ise ögretmenlerinin örgütsel sessizlik davranışlarının orta düzeyde olduğu tespit edilmiştir.

Öğretmenlerin örgütsel sessizliğe yönelik alg1ları arasında okul düzeyi değişkenine göre örgütsel sessizliğin yönetici boyutuna ilişkin algıları arasında istatistiksel olarak anlamlı bir farklılık bulunmazken, okul ortamı, duygu, sessizliğin kaynağı ve izolasyon boyutlarında anlamlı bir farklılık bulunmuştur. Okul 
ortamı boyutunda anlamlı farklllıklar ilkokul öğretmenleri ile lise öğretmenleri ve ortaokul öğretmenleri ile lise öğretmenleri arasındadır. Buna göre ilkokul öğretmenlerinin örgütsel sessizliğin okul ortamı boyutuna yönelik alg1ları, lise öğretmenlerine göre daha düşüktür. Yine ortaokul öğretmenlerinin lise öğretmenlerine göre okul ortamı boyutuna ilişkin algılarının daha düşük olduğu görülmektedir. Bu sonuçlara göre lise öğretmenlerinin örgütsel sessizlik düzeyinin ilkokul ve ortaokul öğretmenlerine göre daha yüksek olduğu belirtilebilir. Örgütsel sessizliğin duygu boyutuna göre anlamlı farklılıklar ilkokul öğretmenleri ile lise öğretmenleri arasındadır. Buna göre ilkokul öğretmenleri örgütsel sessizliğin duygu boyutuna ilişkin alg1ları lise öğretmenlerine göre daha düşüktür. Bunun sebebi sınıf öğretmenlerinin lise öğretmenlerine göre daha okul yöneticileriyle ve diğer öğretmen arkadaşlarıyla çok fazla vakit geçirdiklerinden rahatlikla görüş ve düşüncelerini her konuda açıklayabiliyor olmaları olabilir. Örgütsel sessizliğin, sessizliğin kaynağ1 boyutunda elde edilen sonuçlara göre, anlamlı farklılıklar yine ilkokul öğretmenleri ile lise öğretmenleri arasındadır. Buna göre ilkokul öğretmenlerinin algıları lise öğretmenlerine göre daha düşüktür. Bununla birlikte izolasyon boyutunda da anlamlı farklılık ilkokul öğretmenleri ile ortaokul ve lise öğretmenleri arasındadır. Araştırma sonuçlarına göre ilkokul öğretmenlerinin örgütsel sessizliğin izolasyon boyutuna ilişkin alg1ları daha düşüktür. Bunun sonuçlar, ilkokul öğretmenlerinin birlikte çok vakit geçirdiklerinden, düşüncelerini açıklamalarıyla dışlanmayacaklarını düşünmeleri olarak açıklanabilir. Ateş (2013, s. 73), Ünlü (2015, s. 85) ve Çakal (2016, s. 103), yaptıkları araştırmalarında, örgütsel sessizliğin okul türü değişkenine göre farklllık gösterdiğini tespit etmişlerdir. Yörür de (2016, s. 77) ilk ve ortaokullarda gerçekleştirdiğ çalışmasında branş öğretmenlerinin örgütsel sessizlik düzeylerinin, sınıf öğretmenlerinden anlamlı derecede daha yüksek olduğunu belirlemişlerdir. Yine Sayar (2020, s. 55) araştırmasında ortaokul öğretmenleri örgütsel sessizlik düzeyi algılarını, lise öğretmenlerine göre daha düşük olarak bulmuştur. Dolayısı ile araştırma sonuçlarının birbiriyle tutarlı olduğu görülmektedir.

Öğretmenlerin okullardaki örgütsel öğrenme düzeyi ile örgütsel sessizlikleri arasındaki ilişkilere yönelik sonuçlara bakıldığında ise, örgütsel öğrenmenin sürekli öğrenme, şeffaflık, bilişsel süreçler, soruna yönelik olma boyutlarına yönelik öğretmen algıları ile örgütsel sessizlikleri arasında negatif yönlü orta dereceli bir ilişki tespit edilmiştir. Genel olarak da öğretmenlerin okullardaki örgütsel öğrenme uygulamalarına yönelik algıları ile örgütsel sessizlik düzeyleri arasında anlamlı negatif yönlü orta düzeyde bir ilişki tespit edilmiştir. Elde edilen bu sonuçlara göre, örgütsel öğrenme düzeyinin yüksek olduğu okullarda örgütsel sessizliğin düzeyinin düşmesi beklenebilmektedir. Çünkü örgütsel öğrenmenin hâkim olduğu okullarda, okul çalışanları düşüncelerini özgürce ifade edebilmektedir. Okulda öğretmenler, görüş ve düşüncelerini açıç̧a ifade etmekten çekinirse okulda öğrenme oluşumu engellenecektir (Çakır, 2019, s. 57). Köse'nin (2013, s. 87) yaptığı araştırmada da örgütsel sessizlik ile örgütsel öğrenme arasında ters yönde ve negatif bir ilişki tespit edilmiştir. Bu bağlamda okullarda örgütsel öğrenmenin artması için de örgütsel sessizliğe neden olan etkenlerin araştırılması ve bu nedenlerin ortadan kaldırılması gereklidir. Örgütün gelişebilmesi için, bireylerin öğrendikleri bilgileri örgüt yararına kullanmaları, diğer örgüt çalışanlarıyla paylaşmaları ve ortak amaçlar doğrultusunda çalışmaları gereklidir (Çandır, 2010, s. 25). Araştırmada son olarak da öğretmenlerin okullarda örgütsel öğrenme uygulamalarına yönelik algılarının örgütsel sessizlik düzeylerini anlamlı bir şekilde yordayıp yordamadı̆̆ına yönelikte okullarda örgütsel öğrenme uygulamalarından sürekli öğrenme ve bilişsel süreçler boyutlanının varlı̆̆ının öğretmenlerin örgütsel sessizliklerini yordamadığ1; ancak, örgütsel öğrenmenin şeffaflık ve soruna yönelik olma boyutlarının öğretmenlerin örgütsel sessizliklerini anlamlı bir şekilde yordadığı sonucuna ulaşılmıştır.

Elde edilen sonuçlara göre şu öneriler ileri sürülebilmektedir.

Araştırmaya göre okulların örgütsel öğrenme düzeylerinin yüksek düzeyde olması olumlu bir sonuçtur. Okul düzeyi bazında değerlendirildiğinde okulların öğrenme düzeylerine yönelik ilkokul öğretmenleri ile ortaokul ve lise öğretmenlerinin algıları arasında belirgin bir fark olduğu görülmektedir. Bu durumun sebebinin derinlemesine incelenmesi için nitel bir araştırma yapılabilir.

Araştırma sonuçlarına göre öğretmenlerin okullarda örgütsel sessizliğin okul ortamı ve sessizliğin kaynağ1 boyutlarına yönelik alg1 düzeylerinin düşük olduğu görülmektedir. Örgütsel sessizliğin duygu, yönetici ve izolasyon boyutlarına yönelik algılarının ise orta düzeyde olduğu belirlenmiştir. Okullardaki örgütsel sessizlik düzeyini en aza indirmek için, okullarda öğretmenlerin fikir ve düşüncelerini özgürce ifade edebilecekleri ekip çalışmaları ve yönetime katma vb. uygulamalar oluşturulmalıdır.

Okullarda örgütsel öğrenme düzeyinin yüksek olması ile örgütsel sessizlik arasında negatif yönlü orta düzeyde bir ilişki olduğu tespit edilmiştir. Okullarda örgütsel öğrenmenin daha da arttırılması için yapılacak tüm çalışmalar ve araştırmalar örgütsel sessizliğin de aynı zamanda azalmasını sağlayacaktır. Bu bağlamda 
örgütsel öğrenme için öğrenmenin bir değer olarak okul kültürüne yerleştirilmesi, elde edilen bilgilerin paylaşımının sağlanması ve öğretmenlerin gelişim faaliyetlerinin desteklenmesi gereklidir.

\section{Etik Beyan}

“"Okullarn Örgütsel Öğrenmeleri İle Ögrretmenlerin Örgütsel Sessizllik Düzeyleri Arasindaki İliskę" başl1klı çalışmanın yazım sürecinde bilimsel, etik ve alınt kurallarına uyulmuş; toplanan veriler üzerinde herhangi bir tahrifat yapılmamış ve bu çalışma herhangi başka bir akademik yayın ortamına değerlendirme için gönderilmemiştir. Uygulamalar, Kütahya İl Milli Eğitim Müdürlüğün 24.12.2019 tarih E.25654629 sayllı izni ile yapılmıştır.

\section{Kaynakça}

Alanoğlu, M. (2014). Ortä̈gretim kurumlarmm örgütsel ögrenme düzeylerinin okul etkililiğ̈ ve örgütsel vatandaşhle davramsslarna etkisi (Yüksek Lisans Tezi). Fırat Üniversitesi Eğitim Bilimleri Enstitüsü, Elazığ.

Arlı, D. (2013). İlkokul müdürlerinin örgütsel sessizlik ile ilgili görüşleri. Trakya Üniversitesi Eğitim Fakültesi Dergisi, 3(2), 69-84.

Ateş, S. (2013). Resmi ve özel ilköğretim okullarndaki ögretmenlerin örgütsel sessizliğe ilişkin görüsleri (Kurkkkale ili örneği) (Yayımlanmamış yüksek lisans tezi). Hacettepe Üniversitesi Sosyal Bilimler Enstitüsü, Ankara.

Ay Işık, A.(2017). Okullarn örgütsel öğrenme düzeyleri ile ögrretmenlerin akademik iyimserlikleri arasmdaki ilişski (Yayımlanmamış yüksek lisans tezi). Uşak Üniversitesi Sosyal Bilimler Enstitüsü, Uşak.

Ayden, C. ve Düşükcan, M. (2002). Örgütsel öğrenme kavramı ve öğrenme engellerinin giderilmesinde örgüt kültürü ve liderliğin rolü. SÜ İBF Sosyal ve Ekonomik Araștırmalar Dergisi, 4(2),121-139.

Aydın, Y. (2016). Örgütsel sessizliğin okul yönetiminde kayırmacllk ve öğretmenlerin öz yeterlik algısı ile ilişkisi. Kuram ve Uygulamada Ĕ̈itim Yönetimi Dergisi, 22(2), 165-192.

Aydınl, H. İ. (2005). Örgütsel öğrenme ve oryantasyonlar1. Bilgi Sosyal Bilimler Dergisi, 1, 82-98.

Balay, R. (2004). Öğrenen örgütler. Ögrrenen örgütler (Edt: K. Demir ve C. Elma). Ankara: Sandal Yayınları.

Balc1, A. (2011). Sosyal bilimlerde arastirma yöntem teknik ve ilkeler. Ankara: Pegem Yayıncillk

Basım, H. ve Şeşen, H. (2008). Örgütsel öğrenme ve öğrenen örgütler. Çağdas yönetim ve örgütsel başarm (Edt: Ş. Şimşek ve A. Çelik). Konya: Eğitim Kitabevi.

Bayram, T. Y. (2010). Üniversitelerde örgütsel sessiə̨lik (Yayımlanmamış yüksek lisans tezi). Abant İzzet Baysal Üniversitesi, Sosyal Bilimler Enstitüsü, Bolu.

Bilir, B. ve Arslan, A. (2016). Ortaöğretim kurumlarında görev yapan öğretmenlerin kendi kurumlarına ilişkin öğrenen örgüt algilar1. Abi Evran Üniversitesi Kirşehir Ë̈itim Fakültesi Dergisi (KEFAD), 170(3), $241-260$.

Bozkurt, A. (2003). Öğrenen örgütler. Yönetimde çağdaş yaklaşımlar uygulamalar ve sorunlar (2. Baskı). (Edt: C. Elma ve K. Demir). Ankara: Anı Yayıncilik.

Bursal, M. (2017). SPSS ile temel veri analizleri. Ankara: Anı Yayıncilik.

Büyüköztürk, SS. (2012). Sosyal bilimler için veri analiæ̧i el kitabl: İstatistik, araștrma deseni, SPSS uygulamalar ve yorum. Ankara: Pegem Akademi

Cemaloğlu, N. (2012). Okulun psikolojik yönü. Türk Eğitim Sistemi ve okul yönetimi (Edt: S. Özdemir). Ankara: Pegem Akademi Yayıncilık.

Çakal, G. (2016). Ortä̈gretim kurumlarnda çalısan ögretmenlerin okul yönetimine katılma ile örgütsel sessizllik algzlar arasındaki iliş̧ki (Yayımlanmamış yüksek lisans tezi). Abant İzzet Baysal Üniversitesi, Eğitim Bilimleri Enstitüsü, Bolu.

Çakıc1, A. (2010). Örgütlerde iş gören sessįlliği: neden sessiz kalmayı tercih ediyoruz?? Ankara: Detay Yayınc1lık.

Çakır, E. (2019). Okullarn sosyal sermayesi ile örgütsel ögrenme mekanizmalarmm kullamilması arasindaki iliskinin incelenmesi (Yayımlanmamış yüksek lisans tezi). Necmettin Erbakan Üniversitesi Eğitim Bilimleri Enstitüsü, Konya.

Çalık, T. (2003). Öğrenen örgütler olarak eğitim kurumları. Manas Üniversitesi Sosyal Bilimler Dergisi, 8, 115130.

Çandır, R. (2020). Lise ögrretmenlerinin örgütsel ögrenme düzeyine ilişkin algılar (Yayımlanmamış yüksek lisans tezi). Pamukkale Üniversitesi, Sosyal Bilimler Enstitüsü, Denizli.

Çantuş, T. (2012). Illkögretim okullarnnda örgütsel ögrrenme engelleri (Yayınlanmamış yüksek lisans tezi). Gazi Üniversitesi Eğitim Bilimleri Enstitüsü, Ankara.

Çemberci, M. (2013). Örgütsel öğrenmenin AR-GE takımlarının performansı üzerine etkileri. Akademik Araştrma Dergisi, 57, 95-120.

Dal, H. (2017). Ortaögretim kurumlarnda örgütsel sessizlĭge ilişkin ögrretmen görï̌sleri (Yayımlanmamış yüksek lisans tezi). Hacettepe Üniversitesi, Eğitim Bilimleri Enstitüsü, Ankara. 
Düren, A. Z. (2000). 2000'li yullarda yönetim: Sürekli değişim ve belirsiz̨lik ortamında gelişen ve yönetsel yaklaşımlar (1. Bask1). İstanbul: ALFA Basım Yayım Dağıtım.

Eroğlu, A. H., Adıgüzel, O. ve Öztürk, U. C. (2011). Sessizlik girdabı ve bağlllık ikilemi: İşgören sessizliği ile örgütsel bağlılık ilişkisi ve bir araştırma. Süleyman Demirel Üniversitesi İktisadi ve İdari Bilimler Fakültesi Dergisi, 16(2), 97-124.

Fidanboy, C. Ö., Serpoush, M. ve Yeloğlu, H. O. (2014). Örgütsel sessizlik davranışının örgütsel öğrenmeye etkisi: algılanan örgütsel desteğin aracılık rolü. 2. Örgütsel Davranıs Kongresi, Kayseri, Bildiriler Kitabı (Edt: M. Özdevecioğlu, T. Dedeoğlu, N. Çapar). ss. 753-759.

Gül, H. ve Özcan, N. (2011). Mobbing ve örgütsel sessizlik arasındaki ilişkiler: Karaman İl Özel İdaresi'nde görgül bir çalışma. Kahramanmaraş Sütçü İmam Üniversitesi İktisadi ve İdari Bilimler Fakültesi Dergisi, 1(2), 107-134.

Kahveci, G. ve Demirtaş, Z. (2013). Öğretmenler için örgütsel sessizlik ölçeği geliştirme çalışması. Elektronik Sosyal Bilimler Dergisi, 12 (439,167-182.

Kahveci, G. ve Demirtaş, Z. (2013). Okul yöneticisi ve öğretmenlerin örgütsel sessizlik alg1ları. Ĕ̆gitim ve Bilim, 38(167), 50-64.

Karahan, A. ve Yılmaz, H. (2010). Örgütsel öğrenme, personel güçlendirme ve takım performans1 arasındaki ilişkilerin analiz edilmesi: sağlık sektöründe bir araştırma. Bahkesir Üniversitesi Sosyal Bilimler Enstitüsü Dergisi, 14(25), 136-156.

Karasar, N. (2009). Bilimsel araștırma yöntemi (20. Bask1). Ankara: Nobel yayın dağ1tım.

Kapu, H., ve Aybas, M. (2008). Bilgi ve öğrenme üzerinde tartışmalar ve kapsayıcı bir kavram olarak örgütsel öğrenme yönetimi. Karamanoğlu Mehmetbey Üniversitesi Sosyal ve Ekonomik Araștırmalar Dergisi, 2 , 80-100.

Keklik, B., Kılıç, R., Yıldız, H., ve Yıldız, B. (2015). Sanal kaytarma davranışlarının örgütsel öğrenme kapasitesi üzerindeki etkisinin incelenmesi. Business and Economics Research Journal, 6(3), 129-144.

Keskin, M. B. (2007). Öğrenen organizasyon olma sürecinde ilköğretim okulu yönetici ve ögretmenlerinin vizyon gelistirme düzeyleri (Yayımlanmamış yüksek lisans tezi). Yeditepe Üniversitesi Sosyal Bilimler Enstitüsü, İstanbul.

Kıng1r, S. ve Mesci, M. (2007). Öğrenen organizasyonlar. Elektronik Sosyal Bilimler Dergisi, 6(19), 63-81.

Köse, K. E. (2013). Ilkë̈gretim kurumu ögretmenlerine göre okul yöneticilerinin liderlik stilleri ile örgütsel ögrrenme arasındaki iliskeide örgütsel sessizlik ve karara katılımın aracı etkisi (Yayımlanmamış yüksek doktora tezi). Gazi Üniversitesi, Eğitim Bilimleri Enstitüsü, Ankara.

Kurt, T. (2016). Öğretmen liderliğini açıklamaya yönelik bir model: Dağıtımcı liderlik, örgütsel öğrenme ve öğretmenlerin öz yeterlik algısının öğretmen liderliğine etkisi. Eğitim ve Bilim, 41(183), 1-28.

Mert, G. (2018). Örgütsel ögrenme. İstanbul: Artikel Yayıncilik.

Memduhoğlu, H. B. ve Kuşçi, E. (2012). Yönetici ve öğretmenlerin alg1larına göre ilköğretim okullarında örgütsel öğrenme. İlköğretim Online, 11(3), 748-761.

Nartgün, S. S. ve Kartal, V. (2013). Öğretmenlerin örgütsel sinizm ve örgütsel sessizlik hakkındaki görüşleri. Bartın Üniversitesi Eğitim Fakültesi Dergisi, 2(2), 47-67.

Önder, E. (2017). Ortaöğretim okullarında örgütsel sessizliğin yordayıc1sı olarak örgütsel adalet ve örgütsel bağlllık. Ahi Evran Üniversitesi Kırşehir Eğitim Fakültesi Dergisi, 18(2), 669-686.

Peker, Ö. (1995). Yönetimi geliștirmenin sürekliliği (1. Bask1). Ankara: Türkiye ve Orta Doğu Amme İdaresi Enstitüsü Yayınları No: 258.

Pınar, İ. (2006). Değişim yönetimi anlayışı olarak öğrenen organizasyonlar. Öneri Dergisi, 7(25), 29-42.

Sayar, F. A.(2020). Okullarda örgütsel sessizlik düzeyinin incelenmesi (Yayımlanmamış yüksek lisans tez projesi).Uşak Üniversitesi Sosyal Bilimler Enstitüsü, Uşak.

Seçer, İ. (2013). SPSS ve LISREL ile pratik veri analizi. Ankara: Anı Yayınc1lık.

Senge, P. (2007). Beşinci disiplin (14. Bask1). İstanbul: Yap1 Kredi.

Şehitoğlu, Y., ve Zehir, C. (2010). Türk kamu kuruluşlarında çalışan performansının, çalışan sessizliği ve örgütsel vatandaşlık davranışı bağlamında incelenmesi. Amme İdaresi Dergisi, 43(4), 87-110.

Taşkıran, E. (2011). Liderlik ve örgütsel sessizlik arasindaki etkileşim: Örgütsel adaletin rolü. İstanbul: Beta Basım Yay1m.

Tayfun, A. ve Çatır, O. (2013). Örgütsel sessizlik ve çalışanların performansları arasındaki ilişki üzerine bir araştırma. İsletme Araştırmalar Dergisi, 5(3), 114-134.

Töremen, F. (2001). Ögrrenen okul. Ankara: Nobel Yayın Dağıtım.

Turan, S., Karadağ, E. ve Bektaş, F. (2011). Üniversite yapısı içerisinde öğrenen örgüt ve örgütsel bağlll1k ilişkisi üzerine bir araştırma. Kuram ve Uygulamada Ë̆̈tim Yönetimi, 4(4), 627-638. 
Uçar, R. (2017). Öğretmenlerin örgütsel sessizlik düzeylerinin çeşitli değisşkenler açısından incelenmesi. Uşak Üniversitesi Sosyal Bilimler Dergisi, 10(ERTE Özel Sayıs1), 209-232.

Uysal, R. (2008). İlköğretim okulu ögretmenlerinin örgütsel ögrenme algzlar (Yayımlanmamış yüksek lisans tezi). Yeditepe Üniversitesi, Sosyal Bilimler Enstitüsü, İstanbul.

Üçok, D. ve Torun, A. (2015). Örgütsel sessizliğin nedenleri üzerine nitel bir araştırma. $\dot{I}_{s ̧}$ ve İnsan Dergisi, 2(1), 27-37.

Ünal, A. (2014). Örgütsel öğrenme mekanizmalarının okullarda kullanılması konusunda öğretmen görüşleri. Pamukkale Üniversitesi Eğitim Fakültesi Dergisi, 35, 19-32.

Ünlü, Y. (2015). İlkögrretim ve ortä̈gretim ögretmenlerinin örgütsel adalet alglan ve örgütsel sessiz̨lik düzeyleri arasindaki ilişki (Yayımlanmamış yüksek lisans tezi). Sakarya Üniversitesi, Eğitim Bilimleri Enstitüsü, Sakarya.

Ünlü, Y., Hamedoğlu, M. A., ve Yaman, E. (2015). Öğretmenlerin örgütsel adalet alg1lar1 ve örgütsel sessizlik düzeyleri arasındaki ilişki. Sakarya University Journal of Education, 5(2), 140-157.

Yalçınsoy, A. (2019). Örgüt Kültürü ve örgüt ikliminin örgütsel sessizlik üzerindeki etkisinin analizi. Anemon Mus Aparslan Üniversitesi Sosyal Bilimler Dergisi, 7(2), 67-77.

Yaman, E. ve Ruçlar, K. (2014). Örgüt kültürünün yordayıcısı olarak üniversitelerde örgütsel sessizlik. Journal of Higher Education \& Science/Yülesekögretim ve Bilim Dergisi, 4(1), 36-50.

Yavaş, T. (2012). Ortä̈ğretim okul yöneticileri ve ögretmenlerinin ögrenilmiş çaresizllik, tülkenmislik ve öz-yeterlik algllarmm örgütsel ögrenme düzeylerine etkileri (Yayımlanmamış doktora tezi). Fırat Üniversitesi, Eğitim Blimleri Enstitüsü, Elazığ.

Yazıc1, S. (2001). Öğrenen organizasyonlar (1. Bask1). İstanbul: Alfa Yayınları.

Yllmaz, H. ve Görmüş, A. Ş. (2012). Stratejik girişimciliğin, algilanan örgütsel destek ve örgütsel öğrenme üzerine etkilerinin araştırılması: Tekstil sektöründe ampirik bir çalışma. Journal of Yasar University, 7(26), 4483-4504.

Yörür, F. (2016). İlk ve ortaokullarda görev yapan ögretmenlerin yabanclaşma ve örgütsel sessizlike algzlarn arasindaki ilişki (Yayımlanmamış yüksek lisans tezi). Adnan Menderes Üniversitesi, Sosyal Bilimler Enstitüsü, Aydın.

Zengin, T. ve Gündüz, H. B. (2018). Ortaokul öğretmenlerine göre öğrenen örgüt alg1sı. Yıldı Journal of Educational Research, 3(1), 62-76.

\section{EXTENDED ABSTRACT}

Organizational learning provides opportunities for organizations to adapt to the rapidly changing conditions in the environment and to increase their success. Organizational learning can be defined as the acquisition and implementation of knowledge, ability, value and behavior patterns to ensure the continuity, development and growth of the organization (Basım, \& Şeşen, 2008). The basis of learning in organizations is the learning employee. It is the learning employee who will create the learning teams and ultimately the learning organization (Bozkurt, 2003). The learning required for the existence of organizations takes place in three ways: individual, team and organizational level (Aydinl1, 2005; Bozkurt, 2003; Fidanboy, Serpoush, \& Yeloğlu, 2014; Pınar, 2006; Yılmaz, \& Görmüş, 2012). To make organizational learning possible, first of all, it is necessary to eliminate learning barriers within the organization. Gordon (2009) also expresses learning obstacles for schools as being under the command of teachers due to the hierarchical structure in schools, the inability of teachers to have a voice in the decision stages of schools, rigidity and resistance towards change in school staff and the implementation of non-creative uniform decisions in schools (Çantuş, 2012).

It can be thought that the organizational silence levels of teachers can be reduced by creating an environment for organizational learning in schools and removing the obstacles. The other variable of the research, organizational silence, is that organization employees deliberately unwind their feelings, thoughts, ideas and opinions so that the organization can recover and realize its vision (Kahveci, \& Demirtaş, 2013). Organizational silence can be seen in three ways in organizations. These are acquiescent, defensive, and pro-social silence. In schools where organizational silence prevails, teachers do not communicate deliberately with the school management adequately, and cannot provide them with ideas and suggestions that will ensure their work and development of the school. As a result of organizational silence, sharing of values and information in the school is insufficient, the performance of teachers and administrators decreases and synergy does not arise (Cemaloğlu, 2012). In schools where organizational learning is dominant, school employee can freely express their thoughts. Therefore, organizations should be able to continue their lives by adapting to the developments, and the understanding of continuous 
learning with all employees in the organization should be dominant, and this should be applied in practice (Çakır, 2019; Memduoğlu, \& Kuşçi, 2012).

As can be seen from these explanations, it can be predicted that there is a relationship between organizational learning and organizational silence. Therefore, it can be thought that teachers' organizational silence levels may be low in schools where organizational learning is high. This study aims to determine the relationship between organizational learning of schools and teachers' organizational silence levels. For this purpose, answers to the following questions have been sought:

1. According to the teachers, what is the level of organizational learning in schools? Do the perceptions of teachers regarding the level of organizational learning in schools differ significantly according to the level of school they work at?

2. What are the organizational silence levels of teachers? Do teachers' organizational silence levels differ according to the level of school they work at?

3. Is there a relationship between organizational learning of schools and teachers' organizational silence levels?

4. Do organizational learning practices in schools predict the organizational levels of teachers?

This study aiming to determine the relationship between organizational learning of schools and teachers' organizational silence behaviors is in relational survey model. The population of the research consists of 610 primary, secondary and high school teachers working in Gediz district of Kütahya province in the 2019-2020 academic year; and the research sample consists of 404 teachers. Convenience sampling method has been adopted in the research. The research data have been collected with "Organizational Learning Scale" and "Organizational Silence Scale". In the research, in order to determine what kind of analysis should be done on the data, the skewness and kurtosis coefficients have been paid attention to test whether the data have normally been distributed. Organizational learning practices and organizational silence scales, and skewness and kurtosis coefficients on the data collected indicate that the data are normally distributed. Since the obtained data are among the desired values, one-way analysis of variance ANOVA and Pearson Product-Moment Coefficient and Multiple Regression Analysis have been adopted.

This research has been carried out to determine the relationship between organizational learning in schools and teachers' organizational silence levels. In the research, it is seen that teachers' perceptions about organizational learning in schools are at a high level. Teachers' perceptions of organizational learning in schools differ significantly according to the level of school they work at. Significant differences are between primary school teachers and secondary school teachers and high school teachers. According to the results obtained, primary school teachers think that their schools have higher organizational learning than teachers who work at secondary and high schools. According to the results of the other variable of the research; it is seen that the organizational silences of the teachers are at a moderate level. In the research, it is seen that the perceptions of teachers towards the level of organizational silence in schools are low. While organizational silence levels of teachers do not differ significantly in terms of their perceptions of "manager" dimension according to school level variable, they differ significantly in "school environment, emotion, source of silence and manager" dimensions. Significant differences are between primary school teachers and secondary school teachers and high school teachers. Accordingly, the organizational silence levels of primary school teachers are lower than those of secondary and high school teachers. When the relationship between teachers' organizational learning in schools and teachers' organizational silence levels is analyzed, a significant moderate relationship in a negative way has been found between teachers' perceptions of organizational learning in schools and their organizational silence levels.

It has also been concluded that teachers' perceptions of organizational learning in schools significantly predicted their organizational silence levels. According to the results obtained, the following suggestions can be proposed: There is a clear difference between the perceptions of primary school teachers and secondary and high school teachers towards the learning levels of their schools. A qualitative research can be conducted to deeply examine the cause of this situation. It can be suggested to take measures to minimize the level of organizational silence in schools, and to create environments in schools where teachers can freely express their opinions and thoughts. 